\title{
MITOS KEMATIAN FOTO KARYA OSCAR MATULOH DENGAN PERSPEKTIF ROLAND BARTHES
}

\author{
Siti Desintha ${ }^{1}$, Syarip Hidayat ${ }^{2}$, Ira Wirasari ${ }^{3}$ \\ Universitas Telkom, prodi Desain Komunikasi Visual \\ Jl. Telekomunikasi No. 1, Dayeuhkolot, Bandung \\ Email : 1desintha@telkomuniversity.ac.id, 22syarip@telkomuniversity.ac.id, \\ 3ira@telkomuniversity.ac.id
}

\begin{abstract}
ABSTRAK
Foto jurnalistik menekankan fakta dimana kekuatan berupa ide, gagasan dan naluri kecepatan fotografer dari sebuah peristiwa yang berlangsung singkat. Oscar Matuloh mendokumentasikan jejak gempa tsunami Aceh yang terangkum dalam buku fotografi Soulscape Road. Karya fotografi beliau memberikan gambaran betapa dahsyatnya bencana tsunami yang kemudian menjadi foto essai. Keilmuan fotografi erat kaitannya dengan nilai makna pesan yang terkandung didalamnya. Pada penelitian ini, penulis tertarik untuk meneliti struktur visual dalam fotografi dan mitos karya Oscar Matuloh. Manfaat praktis dari penelitian ini adalah memecahkan masalah perancangan terutama pada desain komunikasi visual mengenai struktur fotografi sebagai media penyampaian pesan yang efektif bagi khalayak sasarannya. Selain itu juga dapat dijadikan sebagai acuan dalam pengembangan fotografi sebagai media penyampaian pesan dan pendidikan. Penelitian ini menggunakan metodologi penelitian kualitatif dengan pendekatan semiotika Roland Barthes. Pemilihan semiotika dikarenakan karya fotografi sejatinya memiliki tanda dan petanda pada setiap visualnya. Adapun tanda dalam fotografi karya Oscar Matuloh merupakan sekuensi kehancuran dan kematian. Karya beliau merupakan sebuah proses perenungan antara manusia dengan Sang Pencipta. Hal tersebut menjadi mitos bagi manusianya itu sendiri dimana mereka menjadi rapuh, tidak ada tempat aman dan nyaman untuk ditempati.
\end{abstract}

Kata Kunci: Fotografi Jurnalistik, Kematian, Mitos. 


\begin{abstract}
Journalism photography is emphasize the fact and the concept where the power is a concept idea and the rate of photographer instinct from the event which come off really quick. Oscar Matuloh is documenting a trace of Aceh earthquake/tsunami which is summarized in the photography book "Soulscape Road". His photography work give a picture, how tremendous the disaster of tsunami which then become a photo essay. Photography closely related with the value of the meaning of the message in it. In this research, the author interested to researching of visual structure in photography and myth, works of Oscar Matuloh. The practical benefits of this research is to solve a design problem especially in visual communication design about the structure of photography as a media delivery for message which effective to the target audience. This research can be made as reference in development of photography as a media delivery for message and education. As an effort of development within extend the knowledge especially in photography on visual communication design. Using the qualitative methodology research with Roland Barthes semiotics approaching. Photography have the sign and signifier on every visual. As for sign in photography by Oscar Matuloh is a sequence of destruction and death. His works is a process of contemplation between human with their own gods become a myth for the human itself, where they are become fragile, without safe place and comfortable place to be occupied.
\end{abstract}

Keywords: Photography, Journalism, Death, Myth

\section{PENDAHULUAN}

Fotografi adalah mendokumentasikan sebuah momen yang menarik serta memiliki arti khusus bagi fotografernya. Menjadi sepenggal cerita yang akan dikenang seumur hidup. Selain itu fotografi juga dipergunakan sebagai media penyampaian pesan atau bahkan mampu untuk mempengaruhi orang. Persepsi manusia dalam melihat suatu gambar atau foto akan berbeda, karena setiap manusia tidak akan selalu sama dalam 'melihat' sesuatu. Namun pada tataran tertentu tetap merujuk pada makna yang sama hanya cara mengutarakannya saja yang mungkin berbeda.
Kamera hanyalah alat yang membantu manusia dalam mengabadikan sebuah objek. Kekuatan terbesar dalam sebuah karya foto adalah ide, gagasan, atau konsep yang diciptakan oleh sang fotografer. Kemampuan secara teknik fotografi pun akan teruji. Cara pengambilan sudut pandang yang berbeda akan mengakibatkan makna yang lain. Walaupun foto tersebut diambil pada saat yang sama. Pada fotografi terdapat bagianbagian berdasarkan kepentingannya. Salah satunya adalah karya foto jurnalistik. Foto jurnalistik adalah foto yang bernilai berita atau foto yang menarik bagi pembaca tertentu dan informasi tersebut disampaikan kepada masyarakat sesingkat mungkin. (Taufan Wijaya, 2011:10) 
Umumnya foto jurnalistik tergantung kepada kecepatan dan naluri fotografer dalam mengambil gambar. Foto tersebut memuat gambar yang secara jelas dan informatif serta dilengkapi dengan caption sehingga ketika melihat foto tersebut dapat secara langsung dan cepat dimengerti. Foto jurnalistik harus memuat pesan atau informasi. Pesan dalam foto jurnalistik bisa sekedar sekuen penting dari sebuah peristiwa yang berlangsung singkat, bisa juga sebuah pesan yang sengaja diciptakan fotografer dari cerita di balik sebuah peristiwa (feature). (Sandono, 2012:4)

Nilai mahal dalam suatu karya foto, dalam hal ini adalah terletak pada ide yang tertanam di masing-masing manusia. Teknik pengambilan gambar merupakan suatu hal yang menjadi keistimewaan bagi setiap fotografer serta menjadikan ciri khasnya. Gambar yang bagus belum tentu memiliki makna, karena ketika orang melihat foto tersebut tidak memberikan pengaruh apapun. Untuk memiliki atau menghasilkan foto yang bermakna harus melibatkan pengetahuan, pengalaman, rasa serta emosi sang fotografer. Hal inilah yang membedakan mana foto yang diambil oleh fotografer amatir atau profesional. Salah satunya adalah kejelian mata dalam melihat dan memaknai sesuatu. Fotografi merupakan koordinasi antara mata, otak, perasaan, jari dan kaki.

Oscar Matuloh seorang fotografer jurnalistik yang sudah memiliki jam terbang yang sangat tinggi dan terlatih. Berbagai prestasi sudah banyak beliau peroleh. Salah satunya adalah ketika beliau merekam jejak bencana alam yang terjadi di Indonesia, khususnya bencana tsunami di Aceh pada tahun 2004. Oscar Motuloh termasuk dalam 30 Most Influential Photographers in Asia atau 30 Fotografer paling berpengaruh di
Asia, seperti dilansir Invisible Photographer Asia (IPA). Beliau terpilih karena pengaruh baik lewat praktek, pendekatan fotografi atau kontribusi dan pengaruhnya dalam komunitas baik secara lokal maupun internasional, sehingga menjadi sebuah ketertarikan untuk dilakukan penelitian (invisiblephotographer.asia, Pemberitaan tanggal 11 Oktober 2013).

Gempa bumi tektonik berkekuatan 8,5 SR berpusat di Samudera Hindia (2,9 LU dan 95,6 BT di kedalaman $20 \mathrm{~km}$ (di laut berjarak sekitar $149 \mathrm{~km}$ selatan kota Meulaboh, Nanggroe Aceh Darussalam) terjadi pada tanggal 26 Desember 2004. Gempa itu disertai gelombang pasang (Tsunami) yang menyapu beberapa wilayah lepas pantai di Indonesia (Aceh dan Sumatera Utara), Sri Langka, India, Bangladesh, Malaysia, Maladewa dan Thailand. Bencana tsunami tersebut tercatat telah menewaskan lebih dari 230.000 jiwa belum termasuk jumlah orang yang hilang. Masyarakat Sumatera sendiri menamakan gempa tersebut sebagai Gempa Bumi Sumatera - Andaman. Para ahli Meteorologi dan Geofisika dari BMKG menyatakan bahwa gempa dahsyat tersebut disebabkan oleh subduksi (pergerakan lempeng tektonik). Tsunami terbesar sepanjang sejarah ini tidak hanya mengakibatkan rusaknya berbagai infrastruktur di kawasan Sumatera saja. Namun di beberapa negara seperti Thailand, Sri Lanka serta Afrika juga mendapatkan dampak yang sama parahnya. Pada saat itu, Indonesia, Maladewa, dan Sri Lanka memberlakukan keadaan darurat karena peristiwa terbesar sepanjang sejarah ini dianggap sebagai bencana nasional.

Gambaran tentang betapa dahsyatnya bencana tsunami kala itu oleh Oscar Matuloh disajikan dalam buku fotografi Soulscape Road. Pada penelitian ini akan dikaji salah 
satu karya foto tersebut serta dibedah melalui semiotika dan kemudian estetika. Estetika erat sekali hubungannya dengan perasaan. Kita selalu menganggap bahwa semua yang indah itu seni dan yang tidak indah itu bukan seni. Identifikasi semacam itu akan mempersulit pemahaman dan apresiasi karya kesenian. Herbert Read dalam bukunya yang berjudul The Meaning of Art mengatakan bahwa seni itu tidaklah harus indah (Dharsono Sony Kartika \& Nanang Ganda Prawira, 2016, www.kumpulansejarah.com/2013/03/sejar ah-peristiwa-tsunami-di-aceh.html).

Sesuatu yang disebut 'indah' adalah yang mampu memberikan kesenangan bagi masing-masing pribadi. Dalam estetika filsafat keindahan oleh Mudji Sutrisno dapat disimpulkan bahwa sebuah karya seni tersebut tercipta berdasarkan emosi, perasaan yang ada dalam diri seniman saat itu. Berdasarkan uraian tersebut maka untuk memperjelas masalah yang akan dibahas yaitu mitos foto karya Oscar Matuloh dengan pendekatan semiotika Roland Barthes, rumusan masalah diurai menjadi mitos serta ideologi yang terbentuk berdasarkan karya tersebut. Metode yang digunakan dalam penelitian ini adalah metode kualitatif dengan menekankan kepada perspektif semiotika dan pendekatan secara estetika. Menurut Bogdan dan Taylor dalam Moleong, (2004:5) "metoda penelitian kualitatif merupakan prosedur penelitian yang menghasilkan data deskriptif berupa katakata tertulis atau lisan dari orang dan perilaku yang dapat diamati."

\section{Pendekatan}

Mengkaji estetika dan mitos dalam foto karya Oscar tema Tsunami melalui pendekatan semiotika Roland Barthes.

\section{Objek Penelitian}

Objek dalam penelitian ini adalah foto jurnalistik Tsunami Aceh karena terdapat makna-makna yang terkandung dalam foto tersebut. Oscar Matuloh dijadikan sebagai subjek dalam penelitian ini.

3. Jenis dan Sumber Data

a) Sumber data primer :

Data yang diperoleh berasal dari wawancara secara langsung dengan senimannya, sebagai narasumber utama, hal ini dilakukan untuk mengetahui latar belakang kehidupan Oscar Matuloh.

b) Sumber data sekunder:

Berbagai studi kepustakaan berupa buku referensi, artikel-artikel, teori tentang semiotika.

4. Teknik Pengumpulan Data

Data dan informasi diperoleh melalui wawancara dan sumber informasi lainnya.

a. Wawancara kepada :

Oscar Matuloh selaku narasumber utama mengenai latar belakang kehidupan dan teknik fotografi yang digunakan dalam pembuatan buku Soulscape Road.

b. Studi Pustaka

1) Buku fotografi: buku tentang foto jurnalistik, sejarah fotografi.

2) Jurnal ilmiah mengenai fotografi, estetika dan semiotika.

Metode analisis data yang dilakukan dalam penelitian ini dengan cara: 


\section{Analisis semiotika}

Semiotik tidak hanya menganalisis tanda (jenis, struktur, makna) secara utuh, namun dapat melingkupi pemahaman tandatanda yang dikombinasikan dalam elemenelemen foto tersebut, mengandung ideologi atau filosofi tertentu yang melatar belakangi terciptanya foto tersebut.

Cara pengkombinasian tanda serta aturan yang melandasinya memungkinkan untuk dihasilkannya makna sebuah teks. Oleh karena hubungan antara sebuah penanda dan petanda bukanlah terbentuk secara alamiah, melainkan hubungan yang terbentuk berdasarkan konvensi, maka sebuah penanda pada dasarnya membuka berbagai peluang petanda atau makna.

\section{TINJAUAN TEORITIK}

Semiotik adalah ilmu yang mengkaji tanda dalam kehidupan manusia. Artinya semua yang hadir dalam kehidupan kita dilihat sebagai tanda yakni sesuatu yang harus kita beri makna. Semiotik pada perkembangannya menjadi perangkat teori yang digunakan untuk mengkaji kebudayaan manusia. Barthes dalam karyanya (1957) menggunakan perkembangan teori tanda Saussure (penanda dan petanda) sebagai upaya menjelaskan bagaimana kita dalam kehidupan bermasyarakat di dominasi oleh konotasi. Roland Barthes melihat tanda sebagai kombinasi dari penanda dan petanda:

\begin{tabular}{|c|c|}
\hline signifier & signified \\
\hline \multicolumn{2}{|c|}{ Sign } \\
\hline
\end{tabular}

Gambar.1

Sumber: Fiske (2007)
Sign (tanda) terbentuk dari signifier (penanda) yang bersifat konkrit yang tak terpisahkan dari signified (petanda) yang bersifat abstrak (Benny H. Hoed, 2011:3).

Dalam aspek teoritis, kajian ini didasari oleh ilmu semiologi Roland Barthes. Teori semiotika Barthes diturunkan dari teori bahasa menurut Ferdinand de Saussure. Barthes membagi dua tingkatan pertandaan yaitu denotasi dan konotasi. Denotasi adalah tingkat pertanda yang menjelaskan hubungan antara penanda dan petanda yang menghasilkan makna yang eksplisit, langsung dalam hal ini adalah makna yang tampak. Konotasi adalah tingkat pertandaan yang menjelaskan hubungan antara petanda dan penanda, yang didalamnya beroperasi makna yang tidak eksplisit, tidak langsung dan tidak pasti (Piliang, 2003:261).

Barthes (dalam Fiske. 2007: 118-119) membagi makna dalam dua ranah: denotasi, yaitu sesuatu (kata) yang tidak mengandung makna atau perasaan-perasaan tambahan; dan konotasi, yaitu sesuatu (kata) yang mengandung arti tambahan, perasaan tertentu atau nilai rasa tertentu disamping makna dasar yang umum.

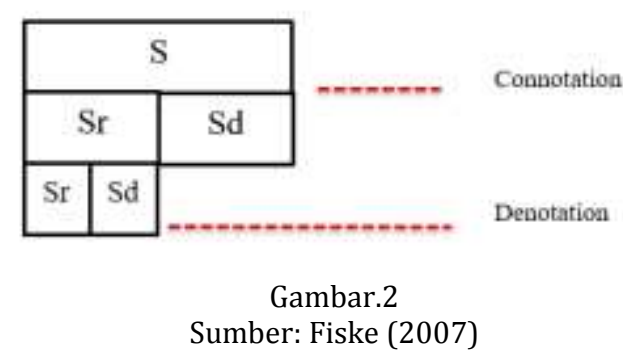

Mitos adalah cerita yang ada pada suatu kebudayaan untuk menjelaskan atau memahami beberapa aspek dari realitas atau alam, demikian yang dikatakan Barthes (dalam Fiske. 2007: 121). Bagi Barthes, mitos merupakan cara berpikir dari suatu kebudayaan tentang sesuatu cara untuk 
meng-konseptualisasi-kan atau memahami sesuatu.

Barthes membuat sebuah model sistematis dalam menganalisis makna dari tanda-tanda, fokus perhatiannya tertuju pada gagasan tentang signifikasi dua tahap (two order signification) seperti terlihat pada gambar berikut:

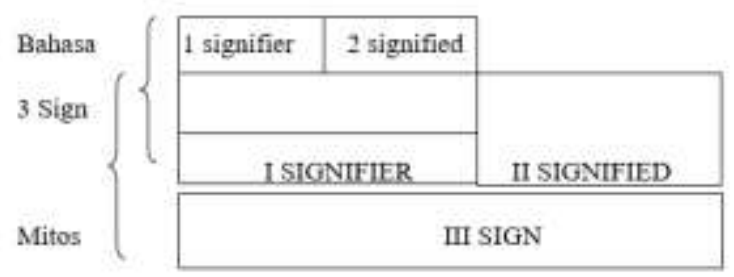

Gambar.3

Sumber: Fiske (2007)

\section{2 Foto Jurnalistik}

Foto jurnalistik penting untuk dipahami karena, dalam hal ini berita sebagai salah satu syaratnya, adalah "sesuatu" yang patut dan perlu dilaporkan dan diketahui orang banyak, karena menyangkut kehidupan di sekitar kita, baik masa kini, masa lalu, dan masa yang akan datang. Jika kita memiliki apapun yang menarik dan dapat menghibur disebut foto feature.

Foto tunggal adalah foto yang banyak disiarkan kantor-kantor berita seperti Lembaga Kantor Berita Nasional Antara, kantor berita Amerika Serikat Associated Press (AP), kantor berita Inggris Reuters, dan kantor berita Prancis Agence France Presse (AFP). Sedangkan foto seri atau foto esai (photo story/photo essay) banyak disiarkan di koran-koran khususnya mingguan.

Foto jurnalistik menurut Guru Besar Universitas Missouri, AS, Cliff Edom adalah paduan kata words dan pictures. Sementara menurut editor foto majalah Life dari 19371950, Wilson Hicks, kombinasi dari kata dan gambar yang menghasilkan satu kesatuan komunikasi saat ada kesamaan antara latar belakang pendidikan dan sosial pembacanya (Audy Mirza Alwi, 2016: Foto Jurnalistik Metode Memotret dan Mengirim Foto).

\section{Karakteristik Foto Jurnalistik}

Foto jurnalistik berbeda dengan foto dokumentasi biasa. Menurut Wilson Hick, ada delapan karakteristik foto jurnalistik yaitu:

1. Keseimbangan data tertulis pada teks gambar adalah mutlak.

2. Medium foto jurnalistik biasanya tercetak, berupa media cetak, kantor berita, koran atau majalah, tanpa memperhatikan tirasnya.

3. Lingkup foto jurnalistik adalah manusia, itu sebabnya seorang foto jurnalistik harus punya kepentingan mutlak pada hal tersebut.

4. Bentuk liputan foto jurnalistik adalah suatu upaya yang muncul dari bakatbakat dan kemampuan dasar seorang jurnalis yang bertujuan melaporkan beberapa aspek dari berita sendiri.

5. Foto jurnalistik adalah fotografi komunikasi, di mana komunikasi bisa diekspresikan seorang fotojurnalis terhadap subjeknya. Objek pemotretan sehingga lebih pantas menjadi subjek aktif.

6. Pesan yang disampaikan dari suatu hasil visual foto jurnalistik harus jelas dan segera bisa dipahami seluruh lapisan masyarakat.

7. Foto jurnalistik membutuhkan tenaga penyunting yang handal, berwawasan visual luas, populis, arif dan jeli dalam menilai karya-karyanya yang dihasilkan serta mampu membina dan mematangkan ide dan konsep sebelum memberikan penugasan. 
8. Kepercayaan yang paling mendasar bagi foto jurnalistik adalah menginformasikan sesuatu yang mutlak dibutuhkan dalam dunia yang mungkin kompleks ini (Workshop Jurnalistik Antara, 2002).

\section{ANALISIS SEMIOTIKA FOTO KARYA OSCAR MATULOH}

\section{Foto yang akan dianalisa:}

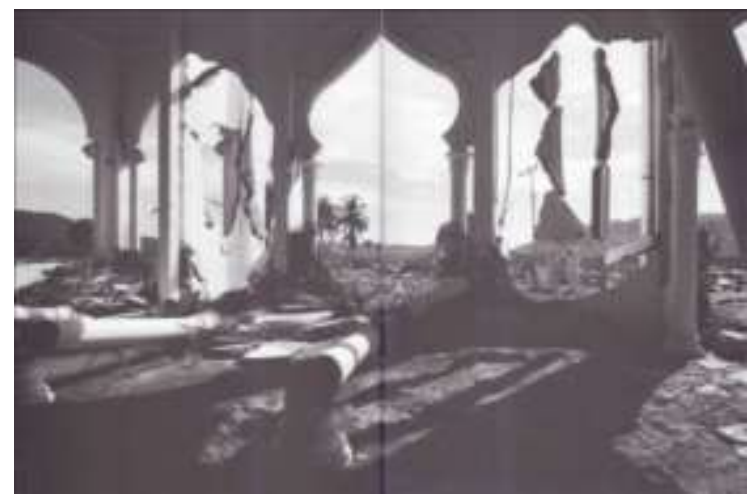

Foto 1 Lhokng, Aceh Sumber: Soulscape Road

Berdasarkan uraian yang telah dibahas di atas, maka didapatkan skema pemaknaan mitos dalam foto jurnalistik tersebut adalah sebagai berikut:

\begin{tabular}{|l|l|}
\hline Masjid & Pilar \\
\hline Kokoh & Cahaya \\
\hline \multicolumn{2}{|c|}{ Kekuatan } \\
\hline
\end{tabular}

Gambar 1. Skema Pemaknaan Mitos Foto Jurnalistik

Dalam pemaknaan tanda tingkat pertama didapatkan hasil analisis bahwa masjid yang memiliki pilar dapat dimaknai kokoh, hal ini disebabkan karena pilar merupakan konotasi dari fondasi, alas, penyangga dan sebagainya. Selanjutnya, pada pemaknaan tanda tingkat kedua makna kokoh yang dimaknai pada tahapan tingkat pertama dikaitkan dengan elemen foto yang lainnya yakni butir-butir pembentuk gambar sehingga didapatkan makna yang kedua yaitu kekuatan. Mitos kekuatan yang dihasilkan oleh foto ini sebenarnya merupakan mitos yang telah lama ada di dalam pemahaman masyarakat mengenai tempat ibadah, seperti telah banyak dilihat dalam beragam jenis visualisasi bahwa tempat ibadah selalu diidentikkan dengan tempat penuh kedamaian, rahmat dan kebaikan. Hal-hal tersebut selalu diidentikkan dengan munculnya cahaya. Sehingga berdasarkan analisis semiotika Barthes foto tsunami karya Oscar Matuloh di atas maka, dapat disimpulkan bahwa bentuk-bentuk teknis di dalam foto tersebut membentuk mitos bahwa masjid yang kokoh tempat menaungi jamaahnya walaupun sudah hancur tetap memiliki fungsi yang sebenarnya yaitu pelindung, dan pemelihara umatnya.

Masjid kokoh yang hancur berantakan oleh tsunami tersebut seolah mengatakan bahwa mitos kekuatan spiritual seolah ingin kembali ditampilkan. Masyarakat yang selama ini diarahkan untuk memiliki untuk bersikap duniawi dan hedonis seolah disadarkan kembali untuk memiliki kepercayaan pada religi, pada spiritual dan yang lebih besar lagi adalah mengingat kembali Pencipta- Nya.

Sebuah mesjid yang hancur, menyisakan beberapa pilar dan gerbang utama.Sisanya rusak parah sampai ke bagian lantainya.Pilar-pilar mesjid yang biasanya kokoh menahan sebuah bangunan kini seakan tidak berdaya. Mesjid adalah rumah tempat ibadah umat Muslim.Mesjid artinya tempat sujud.Pilar merupakan tiang-tiang penyangga suatu bangunan.Terdapat empat buah pilar yang menghadap ke arah gerbang utama.Hanya satu buah pilar yang terlihat masih agak baik dengan bentuk mesjid 
beserta ornamennya. Pada bagian depan terdapat pilar-pilar yang berserakan serta bagian lantai yang terkelupas. Sementara pada bagian luar, terlihat seluruh bangunan hampir rata dengan tanah kecuali gerbang utama dari mesjid tersebut.Juga beberapa pohon kelapa yang masih tegap berdiri.

Pada foto ini, terdapat efek grain yang merupakan butir-butir pembentuk gambar yang menjadi semakin kasar seiring dengan kenaikan sensivitas ISO kamera. Untuk kreatifitas di era film, beberapa fotografer profesional biasa menggunakan film hitamputih lalu memprosesnya sebagai film berISO/ASA tinggi untuk mendapatkan efek grain.Dengan pemakaian yang tepat efek butiran pada gambar dapat membuat gambar terlihat lebih berkarakter dan lebih dramatis.

Foto diambil dengan menggunakan lensa wide, sehingga pada bagian kiri dan kanan terdapat distorsi, namun tidak terlalu besar. Posisi fotografer pada saat mengambil gambar, tepat berada di depan pilar yang masih tampak utuh dari bagian dalam mesjid. Dengan sudut pengambilan secara eye-level, yaitu cara merekam gambar dengan mengambil dari posisi depan subjek, kamera sejajar dengan mata.

Terdapat teknik framing pada pilar-pilar bangunan mesjid tersebut.Framming adalah suatu tahap dimana kita membingkai suatu detail yang telah dipilih sehingga calon fotojurnalis mengenal arti suatu komposisi,pola,tekstur dan bentuk. Foreground yang memperlihatkan pilar-pilar mesjid berjatuhan, lantai mesjid yang terkelupas digantikan oleh tanah pada bagian background memperlihatkan keadaan sekitar yang hancur. Foregroundatau latar depan adalah elemen yang terbentuk oleh objek yang berposisi di depan objek utama. Dengan pengaturan yang baik, latar depan dapat dimanfaatkan untuk menutupi (masking) elemen yang kita anggap tidak terlalu penting, mengarahkan pandang mata ke POI gambar, menciptakan kesan kedalaman atau mengisi area gambar supaya tidak kosong sehingga komposisinya lebih seimbang.

Namun ada yang istimewa pada foto ini, yaitu terdapatnya cahaya-cahaya yang masuk pada mesjid tersebut, ditandai dengan bayangan yang begitu keras menyentuh tanah.Cahaya adalah akar dari fotografi.Setiap cahaya dari sumber dan arah yang berbeda memiliki karakter tersendiri. Cahaya menyorot dari belakang akan menghasilkan bayangan yang memanjang di tanah, berfungsi untuk mengisi kekosongan pada area di depan objek. Cahaya belakang (backlighting) dapat tercipta ketika matahari berada di depan fotografer, mengarah langsung ke kamera.

\section{Foto 2:}

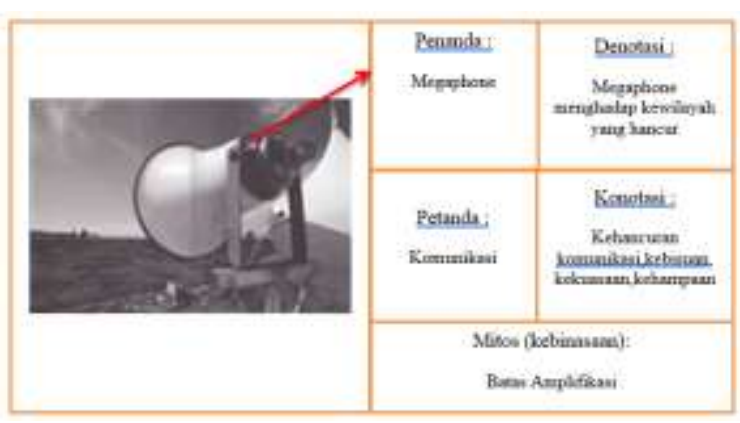

Foto 2 Skema Pemaknaan Foto Jurnalistik Sumber : buku Soulscape Road

Sebuah megaphone yang berada hampir di tengah bidang gambar. Di sebelah megaphone tersebut terdapat kubah mesjid sehingga kita dapat mengetahui keberadaannya. Fungsi dari sebuah megaphone mesjid adalah memberikan informasi yang berkaitan dengan kegiatan keagamaan seperti dikumandangkannya waktu shalat, berita duka, ceramah agama 
dan sebagainya. Posisi megaphone umumya berada di bagian atas sebuah bangunan mesjid. Agar suara tersebut lebih terdengar secara jelas dan merata. Warna megaphone dan kubah mesjid yang sangat kontras dengan background. Terang dan gelap, memberikan kesan yang berbeda. Point of interest semakin jelas terlihat, tidak hanya dari warna yang kontras namun dari bentuknya yang lebih besar.

Bencana sering menjadi lebih menyengsarakan karena sistem komunikasi yang buruk. Seandainya orang-orang diberitahu bahwa pasca gempa akan muncul gelombang tsunami, mungkin korban tidak sebanyak sekarang. Namun, itu semua tidak terjadi. Semua panik ketika gempa berlangsung, evakuasi hanya dilakukan dengan keluar rumah. Tak ada informasi tentang pasca gempa, bahkan media-media yang sebenarnya berpotensi menyebarkan peringatan pada masyarakat luas akhirnya terseret menjadi korban.

Menurut Sullivan (2001: 59), dalam hal ini, kunci komunikasi penanggulangan krisis yang efektif adalah kesiapan sebelum bencana. "The key to effective crisis communication is to be prepared before crisis occurs. Once an emergency happens, there is a little time to think much less to plan, without a crisis plan you can be overwhelmed by events". Apa yang terjadi sekarang, bangsa ini tidak siap menghadapi krisis karena bencana. Bangsa ini tidak siap menghadapi keadaan darurat yang tidak terduga yang akhirnya akan berakibat sangat fatal. Buruknya penanganan bencana dapat memunculkan ketidakjelasan dan ketidakpercayaan bahkan panik.

\section{Analisis Estetika}

Penggunaan komposisi secara horisontal membuat mata kita melihat lebih luas serta teknik framming yang dikombinasikan dengan foreground dan background, seolah-olah kita melihat dalam tiga sisi. Serta penggunaan warna hitam putih semakin memberikan dimensi dalam foto tersebut.

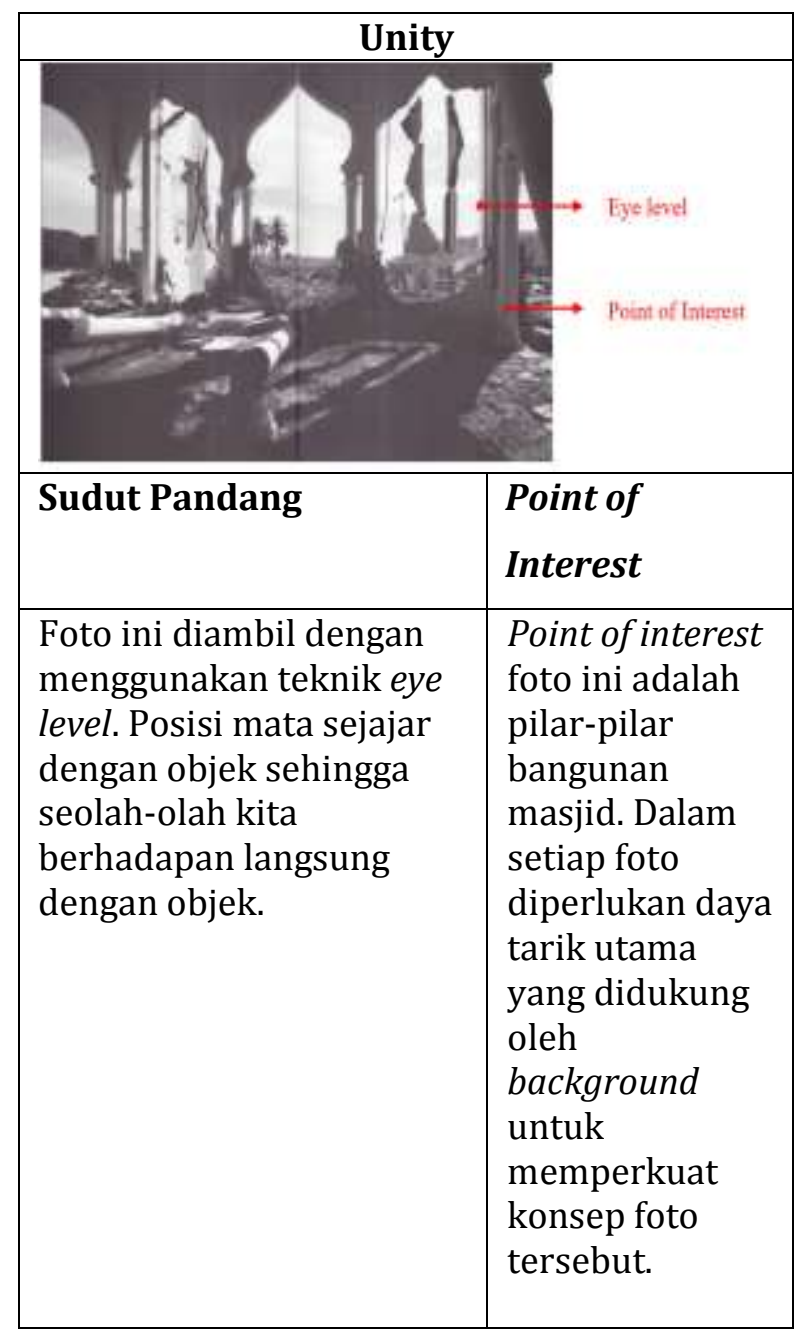

Point of interest foto ini adalah pilarpilar bangunan masjid. Dalam setiap foto diperlukan daya tarik utama yang didukung oleh background untuk memperkuat konsep foto tersebut. 


Organis
Foreground yang memperlihatkan
pilar-pilar mesjid berjatuhan, lantai
mesjid yang terkelupas digantikan oleh
tanah pada bagian background
memperlihatkan keadaan sekitar yang
hancur. Foreground atau latar depan
adalah elemen yang terbentuk oleh objek
yang berposisi di depan objek utama.
$\begin{aligned} & \text { Dengan pengaturan yang baik, latar } \\ & \text { depan dapat dimanfaatkan untuk } \\ & \text { menutupi (masking) elemen yang kita } \\ & \text { anggap tidak terlalu penting, } \\ & \text { mengarahkan pandang mata ke POI } \\ & \text { gambar, menciptakan kesan kedalaman } \\ & \text { atau mengisi area gambar supaya tidak } \\ & \text { kosong sehingga komposisinya lebih } \\ & \text { seimbang.Namun ada yang istimewa } \\ & \text { pada foto ini, yaitu terdapatnya cahaya- } \\ & \text { cahaya yang masuk pada mesjid tersebut, } \\ & \text { ditandai dengan bayangan yang begitu } \\ & \text { keras menyentuh tanah. Cahaya adalah } \\ & \text { akar dari fotografi. Setiap cahaya dari } \\ & \text { sumber dan arah yang berbeda memiliki } \\ & \text { karakter tersendiri.Cahaya menyorot } \\ & \text { dari belakang akan menghasilkan } \\ & \text { bayangan yang memanjang di tanah, } \\ & \text { berfungsi untuk mengisi kekosongan } \\ & \text { pada area di depan objek. Cahaya } \\ & \text { belakang (backlighting) dapat tercipta } \\ & \text { ketika matahari berada di depan } \\ & \text { fotografer, mengarah langsung ke } \\ & \text { kamera. }\end{aligned}$

\section{Analisis Geometri/Struktur Harmoni Foto 2:}

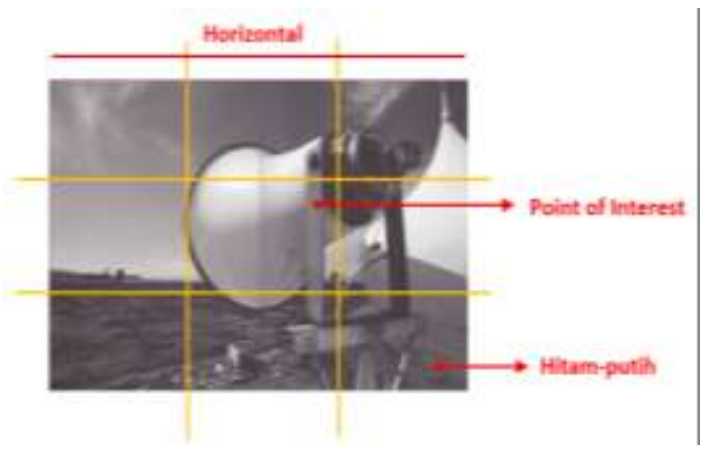

Foto 3 Analisis Geometri/ Struktur Harmoni Foto Jurnalistik

Sumber : buku Soulscape Road

a. Komposisi Foto

Pengambilan foto ini dengan menggunakan teknik rule of third. Bidang foto dibagi menjadi tiga bagian dan objek utama terlihat mendominasi pada sisi kiri, kanan, atas atau bawah sehingga menyisakan ruang yang luas.

\section{b. Warna}

Pengambilan foto menggunakan hitamputih, hal ini menambah kesan foto yang dramatis, elegan dan tak lekang oleh waktu. Selain itu warna hitam putih lebih memfokuskan kita kepada struktur yang terdapat dalam foto tersebut.

\section{c. Ilustrasi}

Sebuah speaker masjid yang berada di sebelah kubah mesjid berada di ketinggian, dilihat dari bangunan kecil yang tersisa (pada bagian bawah). Mengarah pada daratan yang telah kosong dan hancur akibat kedahsyatan bencana tsunami.

\section{d. Garis}

Komposisi secara horizontal memberikan kesan akan luasnya bidang tersebut. Pembagian cerita dalam satu foto namun tetap terlihat teratur dalam penataan. 


\section{Tinjauan Semiotika Foto Karya Oscar Matuloh}

Semiotik, atau dalam istilah Barthes semiologi, pada dasarnya hendak mempelajari bagaimana kemanusiaan (humanity) memaknai hal-hal (things) (Nurhadi \& Sihabul Millah, 2004: Kreasi Wacana). Memaknai (to signify) dalam hal ini tidak dapat dicampuradukkan dengan mengkomunikasikan (to communicate). Memaknai berarti bahwa objek-objek tidak hanya membawa informasi, dalam hal mana objek-objek itu hendak dikomunikasikan, tetapi juga mengkonstitusi sistem terstruktur dari tanda. Salah satu wilayah penting yang dirambah Barthes dalam studinya tentang tanda adalah peran pembaca (the reader). Konotasi, walaupun merupakan sifat asli tanda, membutuhkan keaktivan pembaca agar dapat berfungsi. Barthes secara lugas mengulas apa yang sering disebutnya sebagai sistem pemaknaan tataran ke-dua, yang dibangun di atas sistem lain yang telah ada sebelumnya. sistem kedua ini oleh Barthes disebut dengan konotatif, yang di dalam buku Mythologiesnya secara tegas ia bedakan dari denotatif atau sistem pemaknaan tataran pertama.

Dalam kerangka Barthes, konotasi identik dengan operasi ideologi, yang disebutnya sebagai 'mitos' dan berfungsi untuk mengungkapkan dan memberikan pembenaran bagi nilai-nilai dominan yang berlaku dalam suatu periode tertentu.Di dalam mitos juga terdapat pola tiga dimensi penanda, petanda, dan tanda.Namun sebagai suatu sistem yang unik, mitos dibangun oleh suatu rantai pemaknaan yang telah ada sebelumnya atau dengan kata lain, mitos adalah juga suatu sistem pemaknaan tataran ke-dua.Selain memiliki beberapa penanda, di dalam mitos juga terdapat sebuah petanda.
Oscar melakukan pelaporan atas kejadian tersebut khususnya mengenai Tsunami Aceh. Namun objek yang dipilih Oscar adalah objek-objek ganjil, yang terlupakan oleh manusia dengan kata lain beliau merekam jejak. Hal-hal yang tidak diperhitungkan namun ketika dieksekusi oleh Oscar maka menjadi makna yang lain, lebih dalam. Perahu besar yang seharusnya berada di tengah laut telah berpindah tempat ke daratan, kendaraan berat yang seharusnya berada didaratan telah berpindah ke tengah laut dan sebagainya. Bahkan sebuah boneka panda yang kumalpun dapat menjadi sebuah pesan akan penderitaan.

Berdasarkan teori tersebut terbaca foto Oscar sarat akan penderitaan, kesedihan, ketidakberdayaan manusia dalam berhadapan dengan kekuasaan Tuhan. Halhal tersebut mengisyaratkan sebuah kehancuran dan kematian.

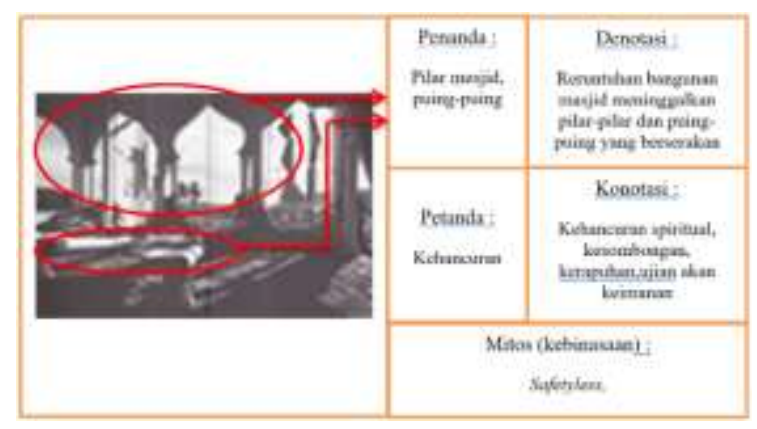

Mesjid merupakan ruang beribadah umat muslim. Aceh memiliki jumlah muslim terbanyak dibanding daerah lain. Mesjid di Aceh merupakan bangunan yang sangat istimewa. Maka dari segi bangunannya pun terlihat indah dan kokoh serta sarat akan nilai filosofi. Tiang-tiang beton yang dibangun sebagai peyangga bangunan memperlihatkan kesombongan manusia. Bencana tsunami mematahkan hal tersebut, kekokohan serta keindahan sebuah bangunan tak lebih dari sesuatu yang mudah 
terkoyak. Kerapuhan terlihat mendominasi dalam foto tersebut. Membagi menjadi tiga bagian yang masing-masing memiliki cerita dan makna. Posisi fotografer berada dibagian dalam mesjid yang mengarah kepada gerbang masuk mesjid. Cahaya matahari yang masuk ke dalam bangunan tersebut untuk mengisi area kosong. Seolah memperlihatkan adanya harapan dibalik sebuah kehancuran yang mampu mempertebal keimanan manusia dikarenakan ketika Tuhan memberikan sebuah musibah yang teramat dahsyat maka akan terdapat hikmah yang luar biasa.

"Reruntuhan Mesjid" bukti nyata bahwa manusia tidak memiliki tempat yang aman dan nyaman sebagai tempat tinggal. Kekokohan dan keangkuhan bangunan tidak lagi menjadi tempat teraman untuk ditempati, tidak ada tempat berlindung menghadapi dominasi alam ini. Tragedi manusia ialah bahwa keinginan untuk meningkatkan keluhuran eksistensinya dan "menyucikan" diri dari sifat-sifat buruk baru muncul setelah manusia melakukan serangkaian kesalahan yang merendahkan derajat kemanusiannya (2013: 457).

\section{Analisis keseluruhan foto 1 dan 2} karya Oscar Matuloh

Dominasi alam menunjukan lemahnya sosok manusia baik itu secara moril atau spiritual. Dominasi alam tidak memandang "sosok" keyakinan seseorang dapat bertahan selamat dari bencana. Kehancuran moril manusia membuat manusia menjadi tidak mempunyai kekuatan spiritual, masjid sebagai simbol spiritual keyakinan manusia pun tidak mampu menundukkan dominasi alam. Masjid sebagai simbol kekuatan keimanan tak mampu mengangkat kekuatan spiritual manusia ketika bencana terjadi. "Reruntuhan Masjid" bermakna kematian spiritual, spiritual dan keyakinan manusia. Manusia seolah menjadi hilang arah karena kehancuran itu. Keimanan yang kokoh seperti bangunan mesjid tersebut menjadi sangat rapuh dan lemah. Semua itu seolah hilang dalam sekejap seperti tsunami yang meluluhlantahkan Aceh hanya dalam hitungan menit.

Menurut karya Teodisi (1710), Leibniz (1646-1716) berkata, kita bisa membayangkan sebuah dunia yang tak sempurna danada kejahatan tanpa harus mempersalahkan Tuhan. Sang Pencipta Yang Maha Kuasa, Maha Bijak, dan Maha Baik itu hanya bisa meyeleksi sebuah dunia yang terbaik dari semua kemungkinan dunia yang terpikirkan (the best of all possible world) (2013: 464).

Voltaire (1694-1778) lewat tokoh Candide menghantam optimism teodisiLeibniz sambil menunjuk pada gempa yang terjadi di Lisabon (1755), empat tahun sebelum Candide terbit.Adagium "Tuhan yang baikmenciptakan sebuah dunia yang baik" tak dapat bertahan dihadapan fakta gambling bumi yang porak poranda karena gempa (2013: 464).

Reruntuhan masjid dan megaphone yang menghadap ke wilayah yang hancur bukti nyata bahwa manusia tidak memiliki tempat yang aman dan nyaman sebagai tempat tinggal. Kekokohan dan keangkuhan bangunan tidak lagi menjadi tempat teraman untuk ditempati, tidak ada tempat berlindung menghadapi dominasi alam ini. Tragedi manusia ialah bahwa keinginan untuk meningkatkan keluhuran eksistensinya dan "menyucikan" diri dari sifat-sifat buruk baru muncul setelah manusia melakukan serangkaian kesalahan yang merendahkan derajat kemanusiannya (2013: 457). 


\section{KESIMPULAN}

Foto jurnalistik Oscar dibedah dengan menggunakan analisis semiologi Roland Barthes untuk mendapatkan pesan dan mitos. Oscar melibatkan pengamatan secara inderawi, objek yang dipilihnya merupakan objek-objek ringan namun ketika digabungkan dalam satu frame mengandung makna serta nilai estetis. Oscar pada saat ke Aceh sudah memiliki simpati terhadap bencana tsunami Aceh sehingga berpengaruh terhadap karyanya.

Tanda dalam foto tersebut adalah kehancuran dan kematian. Sesuatu yang kokoh terlihat rapuh. Dengan adanya cahaya yang mengisi area kosong memberikan harapan di antara kehancuran dan kematian. Salah satu pilar masih terlihat utuh. Kehancuran dan kematian adalah bentuk ujian terhadap keimanan manusia. "Reruntuhan mesjid" bukti nyata bahwa manusia tidak memiliki tempat yang aman dan nyaman untuk ditinggali. Kekokohan dan keangkuhan bangunan tidak lagi menjadi tempat teraman untuk ditempati. Tidak ada tempat berlindung menghadapi dominasi alam ini.

Bencana Tsunami merupakan bencana terdahsyat yang dialami oleh bangsa ini, manusia tidak dapat mengelak dari takdirnya. Maka mitos dari foto tersebut adalah sebuah proses perenungan antara manusia dan Tuhan karena merepresentasikan rasa putus asa, kepasrahan ketika berhadapan dengankuasa-Nya. Adapun teknik yang digunakan Oscar dalam menyajikan foto-foto tersebut terlihat sederhana namun terencana. Foto mengenai bencana dapat menimbulkan traumatis bagi yang melihatnya namun beliau meninggalkan kesan lain ketika kita melihat hasil foto tersebut. 


\section{DAFTAR PUSTAKA}

[1] Alwi, Mirza Audy. 2006. Foto Jurnalistik Metoda Memotret dan mengirim foto ke media massa. Bumi Aksara, Jakarta.

[2] Barthes, Roland. 2007. Membedah Mitos-mitos Budaya Massa. Jalasutra, Yogyakarta.

[3] Fiske, John. 2007. Cultural and Communication Studies. Yogyakarta, Jalasutra.

[4] Gani, Rita dan Ratri Rizki K. 2013. Jurnalistik Foto: Suatu Pengantar. Simbiosa Rekatama Media.

[5] Jaeni. 2012. Komunikasi Estetik: Menggagas Kajian Seni dari Peristiwa Komunikasi Pertunjukan. IPB Press.

[6] Prof. Dr. Nyoman Kutha Ratna, S.U. Cetakan ketiga 2015. Estetika Sastra dan Budaya, Pustaka Pelajar.

[7] Sachari, Agus. 2002. Estetika Makna, Simbol, Daya. ITB.

[8] Sandono, Sri. 2012. Foto Master. RanaKata, Jakarta.

[9] Sutrisno, Mudji, \& C.Verhaak, 1993. Estetika Filsafat Keindahan. Penerbit Kanisisus, Yogyakarta.

[10] Svarajati, Tubagus P. 2013. Photagogos: Terang-Gelap Fotografi Indonesia. SukaBuku, Semarang.

[11] Wijaya, Taufan. 2011. Foto Jurnalistik Dalam Dimensi Utuh. Sahabat. 